\title{
ANALISIS STRUCTURAL EQUATION MODELING KINERJA SISTEM INFORMASI DAN DATA IMUNISASI BALI TINGKAT PUSKESMAS DENGAN MODEL DELONE DAN MCLEAN TAHUN 2020
}

\author{
I Made Esa Sadana Yoga, I Ketut Tangking Widarsa* \\ Program Studi Sarjana Kesehatan Masyarakat, Fakultas Kedokteran, Universitas Udayana \\ *email: twidarsa@yahoo.com
}

\begin{abstract}
ABSTRAK
Sistem Informasi dan Data Imunisasi (SIDI) Bali diterapkan sejak awal tahun 2019 sebagai register pencatatan kohort imunisasi utama dan wajib namun masih ditemui banyak kendala dalam pelaksanaannya khususnya di tingkat puskesmas. Penelitian ini bertujuan untuk mengetahui faktor-faktor yang memengaruhi kepuasan pengguna dan manfaat bersih SIDI Bali tingkat Puskesmas di Provinsi Bali. Penelitian cross-sectional dilakukan pada seluruh petugas imunisasi puskesmas se-Provinsi Bali sebanyak 114 responden. Penelitian dilaksanakan dari Bulan Maret-Juni Tahun 2020. Seluruh data dikumpulkan dengan menggunakan kuesioner yang telah diuji validitas dan reliabilitasnya. Analisis data dilakukan dengan menggunakan analisis Structural Equation Modeling (SEM). Hasil penelitian menunjukan faktor-faktor yang memengaruhi kepuasan pengguna secara signifikan adalah kualitas informasi dan kualitas layanan dengan pengaruh total masing-masing sebesar 0,326 dan 0,241. Faktor-faktor yang memengaruhi manfaat bersih secara signifikan adalah kualitas informasi $(0,379)$, kualitas layanan $(0,337)$ dan kepuasan pengguna $(0,667)$. Upaya yang dapat dilakukan adalah dengan peningkatan kualitas di berbagai aspek dengan cara memperlengkap format luaran sistem, meningkatkan akurasi dan relevansi data, menerapkan NIK anak, adanya supervisor dan tim khusus di setiap kabupaten/kota untuk merespon kendala, dan modul kerja dan modul mengatasi kendala sebagai antisipasi apabila ada pergantian petugas.
\end{abstract}

Kata Kunci: Sistem Informasi, DeLone dan McLean, SEM

\begin{abstract}
Immunization Information and Data System (SIDI) Bali has been implemented since early 2019 as a primary and mandatory immunization cohort register, but there are still many problems encountered in its implementation. This study aims to determine the factors that influence user satisfaction and the net benefits of SIDI Bali at public health center level. A cross-sectional study was conducted on all immunization officers at public health centers in Bali totaling 114 respondents. The study was conducted from March to June 2020. All datas were collected using a questionnaire that had been tested for validity and reliability. The data analyzed using Structural Equation Modeling (SEM). The results of the study based on SEM analysis stated that the factors that significantly influenced user satisfaction were information quality and service quality with a total effect of 0.326 and 0.241 , respectively. Factors that significantly affected net benefits were information quality (0.379), service quality (0.337) and user satisfaction (0.667).Efforts that can be made are to improve quality in various aspects by completing the system output format, increasing the accuracy and relevance of data, implementing children's NIK, having supervisors and special teams in each region to respond the problems, and create work modules and modules addressing problems as anticipate if there is a change of officer.
\end{abstract}

Keywords: Information System, DeLone and McLean, SEM

\section{PENDAHULUAN}

Program imunisasi merupakan salah satu program prioritas pemerintah khususnya di bidang kesehatan, karena imunisasi menjadi kebutuhan yang sangat esensial dan penting untuk pencegahan penyakit menular, sehingga dalam pelaksanaannya wajib tercatat dengan baik dan dilaporkan sesuai dengan keadaan yang sebenar-benarnya. (Kemenkes RI,
2013). Oleh sebab itu, maka setiap daerah dapat mengembangkan sistem pencatatan dan pelaporan data imunisasi tersendiri sesuai dengan kebutuhan informasi yang telah ditetapkan Permenkes dan kemampuan serta sumber daya daerahnya masing-masing termasuk didalamnya Dinas Kesehatan Provinsi Bali. 
Hasil Riset Kesehatan Dasar tahun 2018 menunjukan bahwa hasil cakupan Imunisasi Dasar Lengkap (IDL) di Provinsi Bali mencapai $87 \%$, namun terdapat selisih $17 \%$ lebih rendah dibandingkan data yang dilaporkan secara rutin (Diskes Bali, 2018). Hasil wawancara dengan petugas surveilans Diskes Provinsi Bali menjelaskan hal ini dimungkinkan karena dasar perhitungan capaian imunisasi belum mempergunakan kohort imunisasi dengan baik dan rekapan data masih dalam bentuk manual, sehingga memengaruhi cakupan imunisasi di beberapa fasilitas kesehatan.

Upaya mengatasi situasi tersebut adalah dengan Sistem Informasi dan Data Imunisasi (SIDI) Bali sejak awal tahun 2019, yang merupakan register pencatatan kohort imunisasi utama dan wajib di Bali berbasis Microsoft Excel (Diskes Bali, 2019b). Mengingat pelayanan imunisasi memiliki sasaran yang banyak dan didukung oleh banyaknya faskes, maka dikembangkan beberapa jenis SIDI, salah satunya di tingkat puskesmas.

SIDI tingkat puskesmas sangat memegang peranan penting, selain karena jumlahnya yang banyak yakni 120 buah, posisinya yang strategis dan mendasar menyebabkan apabila terjadi kesalahan baik dari segi pengguna maupun sistem informasi akan berdampak pada hasil pencatatan SIDI tingkat di atas ataupun di bawahnya. Cakupan IDL tahun 2019 ditargetkan sebesar 95\%, namun cakupan IDL beberapa Puskesmas masih lebih rendah dari target atau bahkan di atas 100\% (Diskes Bali, 2019a).

Permasalahan ini dapat terjadi karena dari sisi input, penerapannya yang wajib dan banyaknya petugas imunisasi puskesmas yang sudah berusia lanjut dan kurang dapat menggunakan komputer dengan baik, menyebabkan kesulitan dalam entry dan cleaning data. Selain itu biaya pengembangan sistem agar onlineoffline tidak tersedia, ditambah beban kerja petugas imunisasi yang cukup berat sangat memengaruhi kinerja SIDI Bali ini. Dari sisi proses, pengumpulan data SIDI Bali yang melalui 3 tahapan ditambah harus menunggu umpan balik setelahnya, menyebabkan banyaknya potensi untuk terjadinya kesalahan data dan keterlambatan menyusun laporan. Semua proses ini dilakukan dengan copy-paste formula dan apabila data tidak lengkap dan tidak kohort akan sangat berpengaruh pada validitas output SIDI Bali yakni berupa cakupan imunisasi IDL ataupun per antigennya.

Banyak penelitian yang telah menggunakan analisis kinerja dan evaluasi sistem informasi untuk mengetahui kendala dan kelemahan suatu sistem informasi, salah satunya adalah Jogiyanto (2007) yang menilai sistem berupa suatu proses keberhasilan, seperti proses penilaian, penggunaan, keterlibatan, dan juga proses mencocokan teknologi dengan tugasnya. Salah satu model yang popular digunakan banyak peneliti yang memfokuskan pada keberhasilan implementasi sistem informasi yaitu model yang dikembangkan oleh DeLone and McLean (1992), yang kemudian disempurnakan pada tahun 2003, sehingga dikenal dengan Model Kesuksesan Sistem Informasi DeLone dan McLean.

Model ini mencerminkan proses dan output sebuah sistem informasi yang 
tergantung dari enam pengukuran keberhasilan sistem informasi, yaitu: kualitas sistem (system quality), kualitas informasi (information quality), kualitas layanan (service quality), kepuasan pemakai (user statisfaction), penggunaan (use), dan manfaat bersih (net benefit) (DeLone and McLean, 2003). Enam variabel ini saling terkait satu dengan lainnya dan beberapa penelitian menjelaskan setiap aspek memiliki indikator tersendiri dalam mengukurnya, sehingga membentuk hubungan sebab-akibat yang sangat kompleks. Beberapa penelitian serupa seperti Budiyanto (2009) tentang sistem informasi rumah sakit dan Rahayu (2018) tentang sistem informasi kemahasiswaan, menggunakan analisis SEM (Structural Equation Modeling) untuk mengetahui faktor-faktor keberhasilan sistem informasi dikarenakan banyak dan kompleksnya variabel yang harus diteliti.

Penelitian ini bertujuan untuk mengetahui faktor-faktor apa saja yang memengaruhi kepuasan pengguna dan manfaat bersih SIDI Bali tingkat Puskesmas di Provinsi Bali sehingga dapat memberikan masukan untuk peningkatan kualitas di beberapa aspek pelaksanaan SIDI bagi pihak-pihak terkait.

\section{METODE PENELITIAN}

Penelitian analitik kuantitatif dengan pendekatan cross-sectional dilakukan pada seluruh petugas imunisasi puskesmas di Provinsi Bali berjumlah 120 orang, namun 6 diantaranya dikeluarkan dari penelitian karena tidak memenuhi pengerjaan SIDI dilakukan oleh asisten pribadi atau teknisi puskesmas. Penelitian dilaksanakan dari Bulan Maret-Juni Tahun
2020. Seluruh data dikumpulkan dengan menggunakan kuesioner secara daring dalam bentuk google.doc yang disebarkan ke masing-masing puskesmas melalui petugas kabupaten/kota.

Analisis data dilakukan dengan menggunakan analisis SEM dimulai dari uji asumsi dan persyaratan, analisis deskriptif, analisis faktor konfirmatori dan analisis jalurnya. Variabel bebasnya adalah kualitas sistem, kualitas informasi dan kualitas layanan. Variabel antaranya adalah kepuasan pengguna dan variabel tergantungnya adalah manfaat bersih. Seluruh variabel laten tersebut diukur dengan indikator masing-masing.

Penelitian ini telah mendapatkan persetujuan etik oleh Komisi Etik Penelitian Fakultas Kedokteran Universitas Udayana No: 1057/UN14.2.2VII.14/LT/2020 dan izin melaksanakan penelitian oleh Dinas Penanaman Modal dan Pelayanan Satu Pintu Provinsi Bali No.070/569/IZINC/DISPMPT.

\section{HASIL PENELITIAN}

\section{Karakteristik Responden}

Variabel karakteristik petugas imunisasi tingkat puskesmas yang dianalisis dari penelitian ini adalah umur petugas, jenis kelamin petugas, pendidikan terakhir yang ditamatkan oleh petugas, serta lama petugas bertugas di bidang imunisasi yang terhitung dari awal pengangkatan sampai penelitian berlangsung. Analisis tersebut disajikan dalam table berikut: 
Tabel 1. Karakteristik Responden

\begin{tabular}{ccc}
\hline Karakteristik Responden & Frekuensi (n=114) & Persentase (\%) \\
\hline Umur & 16 & 14,04 \\
$20-29$ tahun & 60 & 52,63 \\
$30-39$ tahun & 31 & 27,19 \\
$40-49$ tahun & 7 & 6,14 \\
$>50$ tahun & & \\
Jenis Kelamin & 9 & 7,89 \\
Laki-laki & 105 & 92,11 \\
Perempuan & & \\
Pendidikan Terakhir & 98 & 85,97 \\
D3 & 3 & 2,63 \\
D4 & 13 & 11,40 \\
S1 & & \\
Lama Bertugas & 18 & 15,79 \\
$<1$ tahun & 56 & 49,12 \\
$1-5$ tahun & 28 & 24,56 \\
$6-10$ tahun & 12 & 10,53 \\
$>10$ tahun & &
\end{tabular}

Analisis tersebut menujukkan bahwa lebih dari setengah petugas imunisasi berusia antara 30-39 tahun. Sebagian besar responden adalah perempuan (92,11\%). Jika dilihat dari pendidikan terakhir yang ditamatkan responden, sebagian besar $(85,97 \%)$ adalah lulusan D3 bidang kesehatan. Berdasarkan lama bertugas di bidang imunisasi, sebagian besar memiliki pengalaman kerja 1-5 tahun (49,12\%), namun $15,79 \%$ petugas baru ditugaskan di bidang imunisasi, sehingga memiliki pengalaman kerja kurang dari 1 tahun (Tabel 1).

Deskripsi Variabel dalam Model DeLone dan McLean

Tabel 2. Gambaran Variabel Laten Model DeLone dan McLean

\begin{tabular}{lcc}
\hline \multicolumn{1}{c}{ Variabel Laten } & Frekuensi (n=114) & Persentase (\%) \\
\hline Kualitas Sistem (Rata-rata skor =14,83) & 69 & 60,53 \\
Baik & 45 & 39,47 \\
$\quad$ Kurang Baik & & \\
Kualitas Informasi (Rata-rata skor =14,92) & 86 & 75,44 \\
$\quad$ Baik & 28 & 24,56 \\
$\quad$ Kurang Baik & & \\
Kualitas Layanan (Rata-rata skor =12,17) & 94 & 82,46 \\
$\quad$ Baik &
\end{tabular}


Kurang Baik

Kepuasan Pengguna (Rata-rata skor $=5,91$ )

Puas

Kurang Puas

Manfaat Bersih (Rata-rata skor $=\mathbf{1 1}, 87$ )

Bermanfaat

Berdasarkan Tabel 2 dan hasil analisis variabel indikator menunjukkan bahwa lebih dari sepertiga responden $(39,47 \%)$ merasa kualitas sistem kurang baik, hal ini utamanya dikarenakan dari dimensi kemudahan sekitar 18\%-22\% petugas merasa SIDI Bali tidak mudah untuk diakses dengan komputer, tidak mudah dipelajari, tidak mudah untuk dimengerti dan tidak mudah digunakan. Dari variabel kualitas informasi 24,56\% responden menyatakan belum berjalan baik, jika dilihat dari indikatornya ketidaksetujuan responden lebih pada dimensi relevansi data tentang kesesuaian sistem dengan harapan responden (11,40\%) dan dimensi akurasi tentang masih terjadinya bias data $(14,03 \%)$ serta ketidaksesuaian dengan kondisi sebenarnya di lapangan (12,28\%). Sementara variabel kualitas layanan sebagian besar menyatakan sudah baik $(82,46 \%)$, ketidaksetujuan responden pada indikator belum mendapatkan pelatihan $(7,89 \%)$ dan respon yang kurang cepat dari pengembang sistem ketika menemui kendala $(7,89 \%)$.

Berdasarkan variabel kepuasan pengguna, lebih dari sepertiga responden $(34,21 \%)$ merasa belum puas. Hal ini dikarenakan dari dimensi efektivitas ketidaksetujuan responden lebih tentang ketidaktepatan waktu untuk dapat menyelesaikan laporan bulanan (12,28\%) serta tidak membantu dalam pencapaian target cakupan $(11,40 \%)$, semenara dari dimensi efisiensi lebih kepada penghematan biaya $(8,77 \%)$ dan bukan merupakan metode yang tepat untuk pencatatan data imunisasi (9,65\%). Berdasarkan variabel manfaat bersih sebagian menyatakan SIDI Bali sudah bermanfaat $(84,21 \%)$, ketidaksetujuan responden terlihat paling utama pada SIDI Bali yang masih dianggap sebagai beban kerja tambahan $(14,04 \%)$ dan belum dianggap meningkatkan produktivitas dalam penggunaannya sejauh ini $(8,77 \%)$.

\section{Hasil Analisis Measurement Model}

Berdasarkan hasil analisis awal, didapatkan bahwa variabel indikator pelatihan dan beban kerja dinyatakan tidak valid dan tidak reliabel, sehingga model harus dimodifikasi dengan mengeluarkan variabel tersebut untuk mengurangi bias dalam analisis selanjutnya. Berikut merupakan variabel indikator akhir yang digunakan dalam analisis SEM: 
Tabel 3. Hasil Confirmatory Factor Analysis Akhir

\begin{tabular}{|c|c|c|c|c|}
\hline Variabel & Validitas Item & $\begin{array}{c}\text { Reliabilitas } \\
\text { Item }\end{array}$ & $\begin{array}{l}\text { Validitas } \\
\text { Konstrak }\end{array}$ & $\begin{array}{c}\text { Reliabilitas } \\
\text { Konstrak }\end{array}$ \\
\hline \multicolumn{5}{|l|}{ Kualitas Sistem } \\
\hline Kemudahan & $0,71^{* *}$ & 0,50 & \multirow{5}{*}{$\begin{array}{c}\text { Valid } \\
(\mathrm{AVE}=2,52)\end{array}$} & \multirow{5}{*}{$\begin{array}{c}\text { Reliabel } \\
(\mathrm{CR}=0,93)\end{array}$} \\
\hline Fleksibelitas & $0,87^{* *}$ & 0,25 & & \\
\hline Keamanan & $0,82^{* *}$ & 0,32 & & \\
\hline Fungsi Spesifik & $0,79^{* *}$ & 0,37 & & \\
\hline Integrasi & $0,75^{* *}$ & 0,44 & & \\
\hline \multicolumn{5}{|l|}{ Kualitas Informasi } \\
\hline Kelengkapan & $0,79^{* *}$ & 0,37 & \multirow{5}{*}{$\begin{array}{c}\text { Valid } \\
(\mathrm{AVE}=2,46)\end{array}$} & \multirow{5}{*}{$\begin{array}{l}\text { Reliabel } \\
(\mathrm{CR}=0,94)\end{array}$} \\
\hline Relevansi & $0,79^{* *}$ & 0,37 & & \\
\hline Akurasi & $0,79^{* *}$ & 0,38 & & \\
\hline Format Luaran & $0,82^{* *}$ & 0,33 & & \\
\hline Terkini & $0,77^{* *}$ & 0,41 & & \\
\hline \multicolumn{5}{|l|}{ Kualitas Layanan } \\
\hline Pendampingan & $0,75^{* *}$ & 0,43 & \multirow{3}{*}{$\begin{array}{c}\text { Valid } \\
(\mathrm{AVE}=2,86)\end{array}$} & \multirow{3}{*}{$\begin{array}{c}\text { Reliabel } \\
(\mathrm{CR}=0,92)\end{array}$} \\
\hline Kecepatan Respon & $0,73^{* *}$ & 0,47 & & \\
\hline Perbaikan & $0,85^{* *}$ & 0,28 & & \\
\hline \multicolumn{5}{|l|}{ Kepuasan } \\
\hline Efektivitas & $0,84^{* *}$ & 0,30 & Valid & Reliabel \\
\hline Efisiensi & $0,92^{* *}$ & 0,16 & $(\mathrm{AVE}=1,41)$ & $(\mathrm{CR}=0,98)$ \\
\hline \multicolumn{5}{|l|}{ Manfaat Bersih } \\
\hline \multicolumn{5}{|l|}{ Peningkatan } \\
\hline Pengetahuan & $0,76^{* *}$ & 0,42 & Valid & Reliabel \\
\hline Produktivitas & $0,84^{* *}$ & 0,29 & $(\mathrm{AVE}=3,11)$ & $(\mathrm{CR}=0,92)$ \\
\hline Dampak Organisasi & $0,71^{* *}$ & 0,49 & & \\
\hline
\end{tabular}

**: Signifikan secara statstik dengan $p$ value $<0,05$

Uji validitas item seluruh variabel indikator diatas dinyatakan valid $(\lambda>0,7)$ dan signifikan yang artinya variasi seluruh variabel indikator dapat dijelaskan dengan baik oleh konstruknya masing-masing. Validitas konstruk didapatkan nilai AVE seluruh konstuk $>0,5$ maka dapat disimpulkan seluruh indikator solid untuk mengukur konstraknya masing-masing. Hasil validitas diskriminan dan multikoleniaritas didapatkan korelasi antar variabel $\leq 0,7$ dan signifikan secara statistik $(\mathrm{p}<0,05)$, artinya setiap konstruk tidak saling berhubungan, yang menunjukkan setiap kontruk adalah unik dan analisis dapat dilanjutkan.

Uji reliabilitas item, hasil analisis data diatas menunjukan bahwa seluruh indikator reliabel $(\delta<0,5)$, artinya seluruh pernyataan secara konsisten telah mengukur apa yang hendak diukur oleh indikator tersebut. Pada analisis reliabilitas 
konstruk, didapatkan nilai CR seluruh konstuk >0,7 maka dapat disimpulkan seluruh indikator secara konsisten telah mengukur konstruknya masing-masing.

\section{Model Persamaan Struktural Tingkat} Kepuasan Pengguna dan Manfaat Bersih dan Faktor yang Berpengaruh

Seluruh data pada variabel indikator berdistribusi normal $(p>0,05)$, serta tidak terdapat data yang outlier dalam penelitian ini sehingga tidak perlu diganti menjadi median. Hasil identifikasi model diperoleh nilai $\mathrm{df}=127(\mathrm{df}>0)$ yang artinya model teridentifikasi, hal ini menunjukan bahwa analisis SEM dapat dijalankan. Hasil uji Goodness of Fit, nilai tes yang diperoleh adalah dengan metode RMSEA sebesar 0,001 $(<0,08)$ dan dengan metode CFI diperoleh nilai tes sebesar 1,00 $(>0,9)$, dapat disimpulkan bahwa model persamaan struktural sudah fit dengan data artinya hasil analisis sudah dapat diterima (Widarsa, 2015). Berikut merupakan gambar hasil akhir model analisis persamaan strukturalnya:

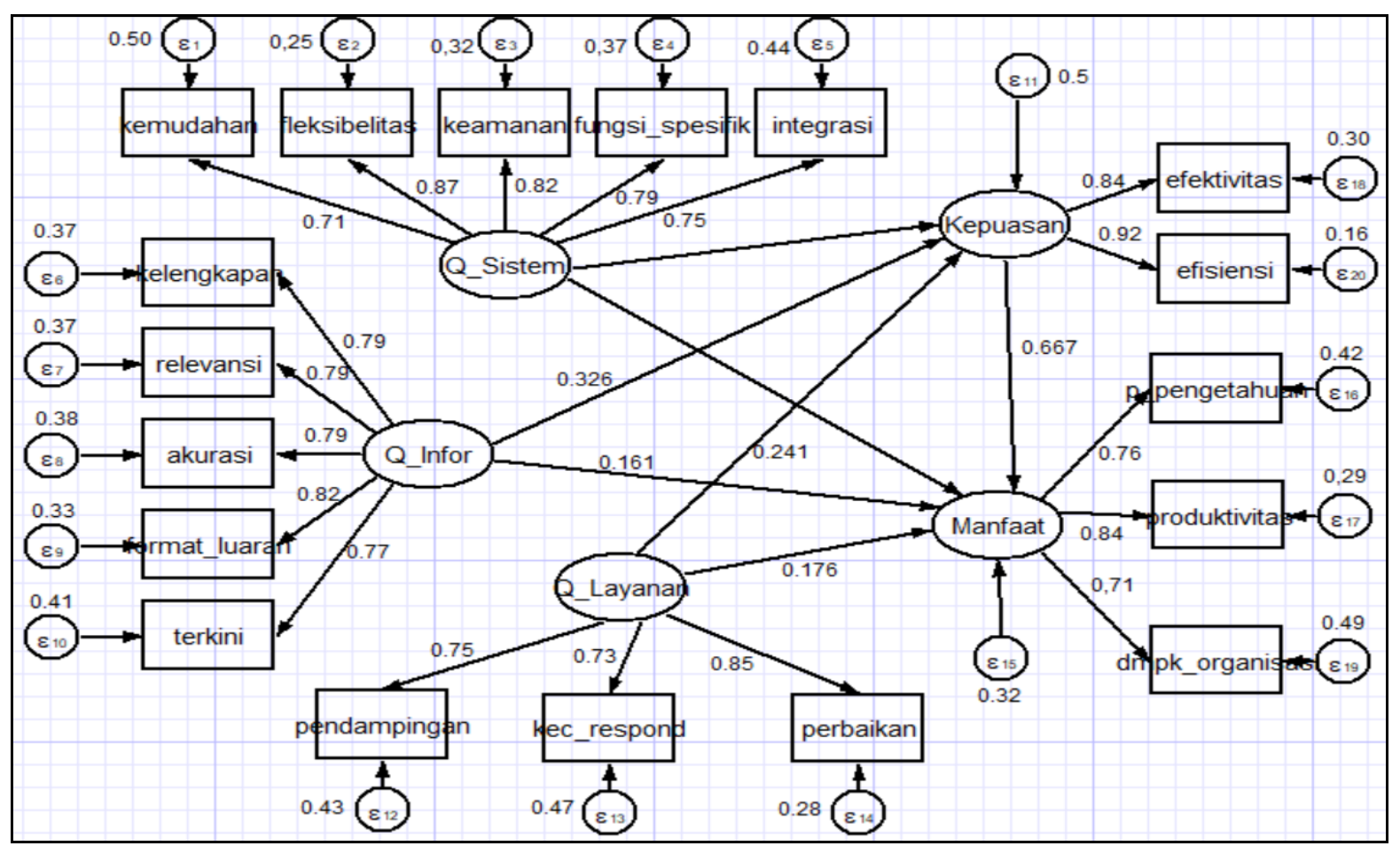

Gambar 1. Model Persamaan Struktural Faktor-Faktor yang Memengaruhi Keberhasilan SIDI Bali Tingkat Puskesmas

Model tersebut terdiri darai 3 variabel eksogen yaitu kualitas sistem, kualitas informasi, dan kuaitas Layanan, serta 2 variabel endogen yaitu kepuasan pengguna dan manfaat bersih. Dalam model struktural ini, manfaat bersih dipengruhi oleh kepuasan pengguna, kualitas sistem, kualitas informasi, dan kualitas layanan. Sedangkan. kepuasan dipengaruhi oleh kualitas sistem, kualitas informasi, dan kualitas layanana. Dalam model ini terdapat 5 model pengkuran, yaitu 1) model pengukuran manfaat bersih yang memiliki 3 indkator, 2) kepuasan pengguna yang terdiri dari 2 indikator, 3) kualitas informasi terdiri dari 5 indikator, 
4) kualitas Informasi erdiri dari 5 indikator, dan 5) kualitas layanan terdiri dari 3 indikator.

Hasil analisis persamaan struktural dari faktor-faktor yang mempengaruhi keberhasilan SIDI Bali tingkat puskesmas berdasarkan Gambar 1. di atas, kemudian disajikan lebih rinci ke dalam tabel-tabel analisis berikut:

Tabel 4. Faktor-Faktor yang Memengaruhi Kepuasan Pengguna

\begin{tabular}{lcccc}
\hline \multicolumn{1}{c}{ Faktor Pengaruh } & Loading Factor & $\mathbf{9 5 \%}$ CI & $\begin{array}{c}\text { Std. } \\
\text { Error }\end{array}$ & $\begin{array}{c}\boldsymbol{p} \\
\text { value }\end{array}$ \\
\hline Kualitas Sistem & 0,006 & $-0,156-0,168$ & 0,827 & 0,943 \\
Kualitas Informasi & $0,326^{* *}$ & $0,211-0,441$ & 0,058 & 0,001 \\
Kualitas Layanan & $0,241^{* *}$ & $0,092-0,389$ & 0,075 & 0,001 \\
\hline
\end{tabular}

**: Signifikan secara statstik dengan $p$ value $<0,05$

Berdasarkan hasil analisis, faktor yang signifikan mempengaruhi kepuasan pengguna dalam menerapkan SIDI Bali tingkat puskesmas adalah kualitas informasi $(p<0,05)$ dengan efek langsung sebesar 0,326 , dan kualitas layanan $(\mathrm{p}<0,05)$ dengan efek langsung 0,241. Sementara kualitas sistem memberikan efek langsung sebesar 0,006 namun tidak signifikan secara statistik.

Tabel 5. Faktor -Faktor yang Memengaruhi Manfaat Bersih

\begin{tabular}{lcccc}
\hline \multicolumn{1}{c}{ Faktor Pengaruh } & $\begin{array}{c}\text { Loading } \\
\text { Factor }\end{array}$ & $\mathbf{9 5 \%}$ CI & $\begin{array}{c}\text { Std. } \\
\text { Error }\end{array}$ & $\begin{array}{c}p \\
\text { value }\end{array}$ \\
\hline Kualitas Sistem & & & & \\
$\quad$ Efek Langsung & 0,126 & $-0,057-0,308$ & 0,930 & 0,176 \\
Efek Tidak Langsung (Kepuasan) & 0,004 & $-0,104-0,112$ & 0,055 & 0,943 \\
Total Efek & 0,130 & $-0,075-0,335$ & 0,105 & 0,215 \\
Kualitas Informasi & & & & \\
$\quad$ Efek Langsung & $0,161^{* *}$ & $0,007-0,314$ & 0,078 & 0,39 \\
$\quad$ Efek Tidak Langsung (Kepuasan) & $0,218^{* *}$ & $0,090-0,345$ & 0,064 & 0,001 \\
$\quad$ Total Efek & $0,379^{* *}$ & $0,231-0,527$ & 0,091 & 0,001 \\
Kualitas Layanan & & & & \\
$\quad$ Efek Langsung & $0,176^{* *}$ & $0,003-0,350$ & 0,089 & 0,047 \\
$\quad$ Efek Tidak Langsung (Kepuasan) & $0,161^{* *}$ & $0,035-0,286$ & 0,064 & 0,012 \\
$\quad$ Total Efek & $0,337^{* *}$ & $0,158-0,516$ & 0,912 & 0,001 \\
Kepuasan Pengguna & & & & \\
$\quad$ Total Efek & $0,667^{* *}$ & $0,343-0,992$ & 0,166 & 0,001 \\
\hline **: Signifikan secara statstik dengan $p$ value $<0,05$ & & &
\end{tabular}


Berdasarkan hasil analisis di atas, kepuasan pengguna berpengaruh signifikan terhadap manfaat bersih dari penggunaan SIDI Bali tingkat puskesmasdengan total efek sebesar 0,667 $(p=0,001)$. Kualitas informasi berpengaruh secara signifikan terhadap manfaat bersih dari penggunaan SIDI Bali tingkat puskesmas dengan total efek sebesar 0,379 $(p=0,001)$ atau sebesar $0,161+0,326^{*} 0,667$ secara langsung dan tidak langsung melalui kepuasan pengguna. Kualitas layanan juga berpengaruh secara signifikan terhadap manfaat bersih dengan total efek sebesar 0,337 $\quad(\mathrm{p}=0,001)$ atau sebesar $0,176+0,241^{*} 0,667$ secara langsung dan tidak langsung melalui kepuasan pengguna. Kualitas sistem tidak memiliki pengaruh yang signifikan terhadap manfaat bersih.

\section{DISKUSI}

\section{Faktor-Faktor yang Memengaruhi Kepuasan Pengguna SIDI Bali Tingkat Puskesmas}

Sebagian besar petugas imunisasi puskesmas memang sudah merasa puas dalam menggunakan SIDI Bali, namun sebanyak $34,21 \%$ petugas belum merasa puas. Hal ini penting karena terkait dengan efektivitas dan efisiensi program yang masih terus dikembangkan, karena dengan meningkatnya kepuasan petugas maka diharapkan SIDI dapat digunakan dengan lebih optimal dalam proses pencatatan dan pelaporan data imunisasi yang akhirnya berdampak pada cakupan imunisasi di Bali.

Kualitas informasi mampu memberikan pengaruh langsung paling besar terhadap kepuasan pengguna yakni sebesar 0,326. Hasil ini sesuai dengan penelitian Bahesa (2018) yang menyebutkan bahwa kualitas informasi merupakan faktor utama dalam mempengaruhi kepuasan pengguna. Kepuasan terhadap sistem informasi ini dikarenakan sebagian besar petugas setuju jika format luaran SIDI sudah cukup lengkap dan relevan, hal ini sejalan degan penelitian Purwaningsih menyebutka bahwa kepuasan pengguna dapat diraih melalui hasil luaran sistem yang lengkap, tidak bias serta aktual dengan kondisi yang sebenarnya.

Kualitas layanan juga memberikan pengaruh yang cukup besar terhadap kepuasan pengguna yakni sebesar 0,241. Penelitian Rahayu (2018) juga menyebutkan bahwa respon baik dari pengembang sistem yang sesuai ekspektasi pengguna akan meningkatkan kepuasan pengguna. Jika dilihat dari analisis deskriptif bahwa sebanyak $82,46 \%$ petugas menyatakan bahwa kualitas layanannya sudah baik karena adanya upaya pelatihan dan pendampingan SIDI tiap bulannya dan perbaikan ketika menemui kendala. Upaya lain untuk terus meningkatkan kualitas layanan menurut penelitian Indrawati (2011) adalah dengan peningkatan kecakapan petugas pengembang program dalam menanggapi permasalahan pengguna melalui pembentukan tim-tim khusus di tiap tingkatan.

Kualitas sistem bukan merupakan faktor yang memengaruhi kepuasan pengguna SIDI Bali. Hasil ini sejalan dengan penelitian Bahesa (2018) yang berpendapat tidak terdapat pengaruh kualitas sistem dengan kepuasan 
pengguna website pemerintah. Radityo, (2007) menjelaskan kualitas sistem artinya kemampuan perangkat keras atau lunak dapat memberikan informasi kebutuhan pengguna. Dalam hal ini petugas imunisasi puskesmas tidak terlibat dalam pengembangan sistem SIDI Bali secara langsung, mereka hanya menerima sistem yang diberikan. Hal ini mengakibatkan petugas tidak terlalu mengetahui kualitas sistem secara mendalam. Penelitian Adi (2007) menjelaskan pentingnya melibatkan konsumen dalam pengembangan sistem informasi untuk keberlanjutan program, agar sistem dapat berjalan baik dengan maksimal.

\section{Faktor-Faktor yang Memengaruhi Manfaat Bersih SIDI Bali Tingkat Puskesmas}

\section{Kualitas Informasi}

Setiap terdapat peningkatan terhadap kualitas informasi maka manfaat bersih yang dirasakan pengguna SIDI Bali tingkat puskesmas akan meningkat sebesar $37,9 \%$ ( $p=0,001)$. Hasil ini didukung oleh Widodo (2013) berpendapat bahwa bila terjadi peningkatan kualitas dalam informasi yang dihasilkan oleh suatu sistem, akan memengaruhi kinerja pengguna dan dampaknya terhadap organisasi. Penelitian ini juga sejalan dengan penelitian yang dilakukan oleh Krisdiantoro (2019) yang menyatakan bahwa adanya pengaruh yang signifikan sebesar 0,171 $(p=0,04)$ antara kualitas informasi dengan manfaat bersih.

Hasil deskriptif menunjukan bahwa sebagian besar petugas menyatakan kualitas informasi sudah berjalan dengan baik, namun terdapat $24,56 \%$ yang berpendapat masih kurang. Jika dilihat dari indikatornya ketidaksetujuan responden lebih pada dimensi relevansi data tentang ketidaksesuaian sistem dengan harapan responden $(11,40 \%)$ dan dimensi akurasi tentang masih terjadinya bias data $(14,03 \%)$ serta ketidaksesuaian dengan kondisi sebenarnya di lapangan $(12,28 \%)$. Bias data dengan kondisi sebenarnya di lapangan dapat terjadi dikarenakan belum berjalanannya sistem penyatuan data yang baik sehingga akan memengaruhi hasil akhir cakupan imunisasi tiap bulannya. Format luaran berupa hasil analisis sistem yang tidak dapat langsung digunakan sebagai laporan bulanan (12,28\%) juga menyusahkan petugas yang memengaruhi kepuasan pengguna. Luaran dari sistem informasi yang baik memang harus sesuai dengan harapan pengguna dan dapat menggambarkan hasil sebenarnya dari data yang terkumpul dalam sistem tersebut dengan mempertimbangkan bias hasil seminimal mungkin (Bahesa, 2018).

Berdasarkan rekapitulasi pendapat yang diberikan responden dari hasil pengumpulan data, petugas menginginkan adanya penetapan NIK anak atau NIK orang tua secara serentak sebagai metode dalam mengkohortkan data imunisasi sehingga tidak terjadi lagi data ganda yang memengaruhi cakupan imunisasi. Perlu adanya pula penyederhanaan dan penyeragaman format laporan bulanan dan evaluasi di seluruh Bali antara SIDI dengan faskes, sehingga hasil perhitungan cakupan pada SIDI dapat langsung digunakan oleh petugas sesuai kebutuhan tanpa mengerjakannya berkali-kali. 


\section{Kualitas Layanan}

Peningkatan terhadap kualitas layanan maka manfaat bersih yang dirasakan pengguna SIDI Bali tingkat puskesmas akan meningkat sebesar 33,7\% $(\mathrm{p}=0,001)$. Hasil ini didukung oleh teori Jogiyanto (2007) dimana dengan adanya peningkatan terhadap kualitas layanan dalam sebuah sistem, maka pengguna akan merasa tidak terbebani ketika menemui masalah dalam menggunkan sistem sehingga proses kerja akan lebih produktif. Penelitian ini juga sesuai dengan penelitian yang dilakukan oleh Anggih (2014) yang menyatakan bahwa adanya pengaruh yang signifikan antara kualitas layanan dengan manfaat bersih sebesar 0,635 ( $p=0,007)$.

Dari seluruh responden, 15,79\% petugas baru ditugaskan di bidang imunisasi sehingga memiliki pengalaman kerja kurang dari 1 tahun dimana 33,33\% diantaranya menyatakan kualiatas layanan kurang baik. Hal ini dapat terjadi karena mereka tidak mengenal SIDI Bali dari awal penerapannya sehingga kesulitan dalam memahami sistem baru, ditambah situasi pandemik yang menyebabkan tidak memungkinkan diadakannya pelatihan secara langsung. Ketidaksetujuan responden juga terlihat pada indikator respon yang kurang cepat dari pengembang sistem ketika menemui kendala $(7,89 \%)$, hal ini dikarenkan hanya ada satu orang petugas provinsi atau kabupaten/kota yang bertugas dalam melakukan respon perbaikan sehingga membutuhkan waktu yang cukup lama.

Pendampingan dalam penggunaan sistem sangat penting karena setiap petugas harus memiliki kompetensi yang sama (Rokhman, 2015), mengingat SIDI
Bali adalah sistem yang terintegrasi satu dengan lainnya, karena akan memengaruhi hasil cakupan imunisasi. Selain itu masih adanya hirarki sungkan untuk bertanya dari petugas puskesmas apabila menemui kendala karena pengembang sistem dianggap sebagai atasan dalam bekerja juga memengaruhi ketepatan waktu pengumpulan data.

Berdasarkan rekapitulasi pendapat yang diberikan responden dari hasil pengumpulan data, adapun saran yang diberikan yakni dengan dibuatkannya tim khusus yang sudah terlatih di setiap kabupaten/kota untuk membimbing petugas baru dan merespon setiap kendala agar lebih cepat, selain itu perlu adanya modul mengatasi kendala agar petugas dapat dengan cepat mengatasi kendalanya sendiri, dan petugas baru juga tidak kebingugan dengan sistem ini.

\section{Kualitas Sistem}

Kualitas sistem bukan merupakan faktor yang memengaruhi manfaat bersih SIDI Bali tingkat puskesmas. Hasil ini tidak sesuai dengan penelitian Krisdiantoro (2019) yang menyatakan bahwa bila suatu system informasi dapat menampilkan kualitas sistem yang tinggi, maka akan dapat memberikan keuntungan bersih pada pemangku kepentingan, termasuk individu, kelompok individu, dan organisasi. Namun dalam penelitian menunjukan hasil yang berbeda, dimana masih terdapat $39,47 \%$ petugas yang merasa kualitas sistem masih kurang baik.

Dilihat dari karakteristiknya sebanyak $33,33 \%$ petugas berusia diatas 40 tahun dimana sekitar $44 \%$ diantaranya menyatakan kualitas sistem belum berjalan 
baik. Hal ini dikarenakan kurangnya kemampuan mereka dalam menggunakan computer dan aplikasinya dengan baik. Jika dilihat dari indikatornya ketidaksetujuan responden dikarenakan dari dimensi kemudahan sekitar 18\% - 22\% petugas merasa SIDI Bali tidak mudah dipelajari, tidak mudah untuk dimengerti dan tidak mudah digunakan. Selain itu integrasi data juga belum berjalan dengan baik $(9,65 \%)$, karena sudah terbiasanya petugas menggunakan sistem pencatatan secara manual selama bertahun-tahun, dan tidak melakukan integrasi data cakupan dengan petugas lain karena hanya menggunakan data agregat yang dianggap masih lebih mudah.

Berdasarkan rekapitulasi pendapat yang diberikan responden dari hasil pengumpulan data, saran yang diberikan responden umumnya yakni mulai diterapkannya sistem online-offline melalui sistem website sehingga data dapat terkumpul dalam satu server sehingga setiap petugas memiliki sistem yang sama tanpa khawatir perbedaan versi aplikasi dan lainnya. Data tiap petugas juga akan lebih aman dan terintegrasi dengan petugas lainnya sehingga lebih mudah dalam pengumpulan dan pelaporan data, serta mengurangi kerusakan dan erorr dari rumus dalam Excel.

\section{Kepuasan Pengguna}

Setiap terdapat peningkatan terhadap kepuasan pengguna maka manfaat bersih yang dirasakan pengguna SIDI Bali tingkat puskesmas akan meningkat sebesar $66,7 \%(p=0,001)$. Hasil ini didukung oleh teori Jogiyanto (2007) dimana kepusasan pengguna yaitu respon umpan balik yang diberikan oleh pengguna setelah memakai sistem informasi sehingga dapat memengaruhi kebermanfaat sistem baik secara individual maupun organisasi tempat sistem dijalankan. Penelitian ini sependapat dengan penelitian yang dilakukan oleh Salim (2014) yang menyatakan bahwa adanya pengaruh yang signifikan antara kualitas informasi dengan manfaat bersih sebesar $0,718 \quad(p=0,001)$ baik secara langsung maupun tidak langsung.

Hasil penelitian menunjukan lebih dari sepertiga petugas belum merasa puas $(34,21 \%)$ terkait dengan efektivitas dan efisiensi SIDI. Efektivitas berkaitan dengan pencapaian tujuan, ketepatan waktu dan adanya kendala yang dirasakan, sementara efisiensi berkaitan dengan pengelolaan sumber daya dengan optimal (Riyardi, 2011). Dari dimensi efektivitas ketidaksetujuan responden tentang ketidaktepatan waktu untuk menyelesaikan laporan bulanan (12,28\%) serta tidak membantu dalam pencapaian target cakupan $(11,40 \%)$ oleh karena semua petugas saling tunggu apabila terjadi kendala pada SIDI karena sifatnya yang harusnya terintegrasi. Sementara dari dimensi efisiensi lebih kepada tidak menghemat biaya (8,77\%) dan bukan merupakan metode yang tepat untuk pencatatan data imunisasi $(9,65 \%)$ karena petugas selalu membandingkan dengan sistem pencatatan sebelumnya yang lebih sederhana dan sendikit kendala namun sebenarnya sangat bias.

Kepuasan terhadap penggunaan suatu sistem informasi akan menentukan produktivitas dan meringankan beban kerja pekerja sehingga kebermanfaatan 
sistem akan lebih dirasakan (Jogiyanto, 2007). Oleh karena itu diperlukan peningkatan pada dua dimensi tersebut melalui evaluasi pada kualitas informasi dan kualitas layanan karena terbukti memberikan pengaruh tidak langsung kepada manfaat bersih melalui kepuasan pengguna secara signifikan.

\section{SIMPULAN}

Sebanyak $65,79 \%$ petugas merasa puas menggunakan SIDI Bali tingkat puskesmas, dimana kepuasan pengguna ini dipengaruhi secara signifikan oleh faktor kualitas informasi dengan total efek sebesar 0,326 dan kualitas layanan dengan total efek sebesar 0,241. Sebanyak 84,21\% petugas merasa SIDI Bali tingkat puskesmas bermanfaat, dimana manfaat bersih ini dipengaruhi secara signifikan oleh faktor kualitas informasi dengan total efek sebesar 0,379, kualitas layanan dengan total efek sebesar 0,337, dan kepuasan pengguna dengan total efek sebesar 0,667.

\section{SARAN}

Diskes Provinsi Bali diharapkan memperlengkap format luaran sistem, menerapkan format online-offline sistem, menerapkan NIK anak untuk mempermudah pencatatan dan pengkohortan, dan adanya modul kerja dan modul mengatasi kendala sebagai antisipasi apabila ada pergantian petugas. Diskes kabupaten/kota dapat membentuk supervisor dan tim khusus untuk merespon kendala dan memberikan perbaikan, dan dapat mengadakan evaluasi berkala tidak hanya di tingkat puskesmas tetapi juga di tingkat pustu dan jejaring lainnya. Disarankan kepada peneliti selanjutnya agar lebih meneliti lagi variabel kualitas sistem dengan model keberhasilan lain.

\section{DAFTAR PUSTAKA}

Adi, P. H. (2007). Partisipasi Pengguna Dalam Pengembangan Sistem Informasi (Telaah Literatur). Jurnal Akuntansi dan Keuangan, 8(1), pp52.

Anggih, R. (2014) Pengaruh Kualitas Informasi, Kualitas Sistem, Dan Kualitas Layanan Terhadap Kepuasan Pengguna Pada Sistem Informasi Klinik. Universitas Negeri Yogyakarta. Available at: https://eprints.uny.ac.id/11165/

(Accessed: 2 June 2020).

Bahesa, B. P. (2018) TA: Analisis Kesuksesan Sistem Informasi Website Pemerintah Kabupaten Pamekasan Berdasarkan Model Delone and Mclean. . Institut Bisnis dan Informatika STIKOM Surabaya. Available at: http://repository.dinamika.ac.id/id/ep rint/2883 (Accessed: 2 June 2020).

Budiyanto (2009) Evaluasi Kesuksesan Sistem Informasi Dengan Pendekatan Model Delone Dan Mclean (Studi Kasus Implementasi Billing System di RSUD Kabupaten Sragen), Tesis. Universitas Sebelas Maret. doi: 10.1159/000448528.

DeLone, W. H. and McLean, E. R. (1992) 'Information systems success: The quest for the dependent variable', Information Systems Research. 
INFORMS Inst.for Operations

Res.and the Management Sciences, 3(1), pp. 60-95. doi: 10.1287/isre.3.1.60.

DeLone, W. H. and McLean, E. R. (2003) 'The DeLone and McLean model of information systems success: A tenyear update', in Journal of Management Information Systems. M.E. Sharpe Inc., pp. 9-30. doi: 10.1080/07421222.2003.11045748.

Diskes Bali. (2018). Data Cakupan Imunisasi Provinsi Bali Tahun 2018. Dinas Kesehatan Provinsi Bali.

Diskes Provinsi Bali (2019a) Data Cakupan Imunisasi Provinsi Bali Tahun 2019.

Diskes Provinsi Bali (2019b) Petunjuk Teknis Sistem Informasi dan Data Imunisasi (SIDI) Bali.

Indrawati, A. (2011). Pengaruh Kualitas Layanan Lembaga Pendidikan terhadap Kepuasan

Konsumen. Jurnal Ekonomi

Bisnis, 16(1), 25-35.

Jogiyanto, H. M. (2007). Model Kesuksesan Sistem Teknologi Informasi. Yogyakarta: Penerbit Andi.

Kemenkes RI (2013) Peraturan Menteri Kesehatan Republik Indonesia Nomor 42 Tahun 2013. Tentang Penyelenggaraan Imunisasi.

Krisdiantoro, Yuyut, dkk (2019) ‘Pengaruh Kualitas Sistem dan Kualitas Informasi terhadap Manfaat Bersih dengan Intensitas Penggunaan sebagai Variabel Mediasi I
Krisdiantoro | Jurnal Akuntansi Aktual', Jurnal Akuntansi Aktual, 6, pp. 261-279. Available at: http://journal2.um.ac.id/index.php/ja a/article/view/6678 (Accessed: 2 June 2020).

Panjaitan, E. S., Hasibuan, S. F., Ula, N. M., \& Sembiring, S. (2019, August). Analisis Faktor-Faktor yang Mempengaruhi Manfaat Bersih yang di Mediasi oleh Kepuasan Pengguna Sistem Informasi Administrasi Kependudukan. In Seminar Nasional Sains dan Teknologi Informasi (SENSASI) (Vol. 2, No. 1).

Purwaningsih, S. (2010) 'Analisis Kesuksesan Penerapan Sistem Informasi pada Sistem Informasi Pelayanan Terpadu (SIPT) Online (Studi Pada PT Jamsostek (PERSERO))', Jurnal Ilmiah Aset, 12(2), pp. 181-189.

Radityo, Dody, D. (2007) Pengujian Model DeLone and McLean Dalam Pengembangan Sistem Informasi Manajemen (Kajian Sebuah Kasus). Universitas Hasanudin, Makasar.

Rahayu, Flourensia Saptya, dkk (2018) 'Analisis Kesuksesan Sistem Informasi Kemahasiswaan (SIKMA) dengan Pendekatan Model DeLone dan McLean', Indonesian Journal of Information Systems. Universitas Atma Jaya Yogyakarta, 1(1), pp. 3446. doi: 10.24002/ijis.v1i1.1704.

Riyardi, A. and Widojono, W. (2011) 'Analisis Efisiensi, Efektivitas dan Responsibilitas Kapasitas Sumber 
Daya Manusia Pemerintah Daerah Sragen', Analisis Efisiensi, Efektivitas

Dan Responsibilitas Kapasitas Sumber Daya Manusia Pemerintah Daerah Sragen, 4(2). doi: 10.15294/jejak.v4i2.4644.

Rokhman, N., Budi, S. C. and Nuryati, N. (2015) 'Optimalisasi Sistem Informasi Puskesmas pada Layanan Kesehatan di Puskesmas Dlingo I Kabupaten Bantul Yogyakarta', Jurnal Pengabdian kepada Masyarakat (Indonesian Journal of Community Engagement). Universitas Gadjah Mada, 1(1), pp. 133-142. doi: 10.22146/jpkm.16960.

Salim, M. I. (2014). Analisis Kesuksesan Sistem Informasi Perpustakaan Senayan Dengan Pendekatan Model Delone dan Mclean Di SMK Muhammadiyah 3

Yogyakarta. Universitas Negeri Yogyakarta.

Widodo, T. W., Handayani, S. R., \& Saifi, M. (2013). Pengaruh Aplikasi Sistem Informasi Manajemen (SIM) Terhadap Kinerja Karyawan (Studi Kasus pada Usaha Kecil Menengah Bidang Usaha Warnet di Kota Malang). Profit: Jurnal Administrasi Bisnis Universitas Brawijaya,7(1), 162648.

Widarsa, T. (2015) Modul Pelatihan Analisis Multivariat dan Pemodelan Persamaan Struktural. Universitas Udayana. 